\title{
ОЛЕНА МИХАЙЛІВНА ВЕЛИЧКО
}

Народилася Олена Михайлівна в м. Києві 2 грудня 1951 року в робітничій родині. Батько, переживши буремні роки війни, тяжко хворів і рано пішов із життя. У далекому 1970 році, коли вона після закінчення школи, працюючи макетувальникоммонтажистом у друкарні, вступила на перший курс Київського вечірнього факультету Українського поліграфічного інституту ім. Івана Федорова, навіть і не думала про наукову кар'єру. Але з часом життя внесло свої правильні корективи.

Після закінчення вузу О. М. Величко працювала на виробництві технічним та художнім редактором, потім спочатку молодшим, а згодом і старшим науковим співробітником у науково-дослідних установах - Київських філіях ДіпроНДІПоліграфа та ВНДІ Поліграфії. Останній в роки незалежності отримав назву ВАТ «Український науково-дослідний інститут спеціальних видів друку» («УкрНДІСВД»). Робота була цікавою, напруженою, успішною, іноді з надмірними хвилюваннями і турботами, однак наповненою яскравими подіями, які, безумовно, зустрічаються в житті кожної людини. Результатом багаторічної роботи на виробництві і в науці став захист у 1984 році дисертації на здобуття наукового ступеня кандидата технічних наук та отримання у 1992 році вченого звання старшого наукового співробітника. Закономірним стало й запрошення на викладацьку роботу до ВПІ НТУУ «КПІ».

Розробка робочих навчальних програм, підготовка лекцій,

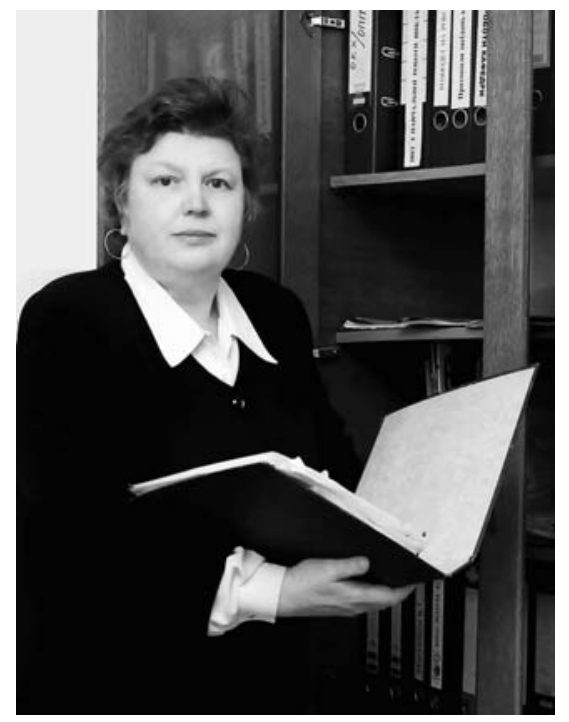

практичних і лабораторних робіт, індивідуальних контрольних завдань, екзаменаційних білетів вимагають від викладача глибоких знань предмету, потреб галузі, широкої ерудиції в різних сферах життя. Тут знову довелося наполегливо і творчо працювати весь час.

Студенти поважають Олену Михайлівну не тільки за цікаві та змістовні лекції й практичні заняття, а й за її принциповість, уважність, високі вимоги до змісту та технічного оформлення контрольних робіт, пояснювальних записок курсових і дипломних проектів. Таку вимогливість вона проявляє повною мірою й до її власних публікацій. Адже вона опублікувала понад 160 наукових праць в Україні, Росії, Польщі, у тому числі статті, тези доповідей на конференціях різних рівнів, 4 монографії, 2 навчальні посібники з грифом МOH України, які одержали широкий резонанс серед поліграфічної 
громадськості, отримала 13 авторських свідоцтв і патентів України. Усі її праці ретельно підготовлені, чітко виписані, а головне - відрізняються цікавими ідеями, новими підходами. А це приваблює вдумливих і сумлінних студентів, талановитих аспірантів і творчих практиків галузі, які бажають розширити свої знання, набути навичок дослідницької роботи. Тому не зменшується кількість охочих бути серед іï̈ учнів: спеціалістів, магістрів, аспірантів. Олена Михайлівна за роки роботи у ВПІ НТУУ «КПІ» підготувала більше 80 бакалаврів і спеціалістів, а тепер готує магістрів і керує науковою роботою аспірантів. Двоє 3 них вже захистили кандидатські дисертації, а троє підготували наукові роботи до захисту.

Олена Михайлівна відповідальний виконавець, ентузіаст і творча особистість, ініціатор і член організаційного комітету Міжнародної науково-технічної конференції студентів і аспірантів «Друкарство молоде», заступник головного редактора збірника наукових праць «Технологія і техніка друкарства» ВПІ НТУУ «КПІ», член редакційних колегій збірників наукових праць «Поліграфія і видавнича справа» та «Наукові записки», які видаються Українською академією друкарства.

Захист докторської дисертації 30 червня 2006 року підтвердив, що Олена Михайлівна є науковцем високого рангу. У своїй докторській дисертації О. М. Величко, зокрема, розглянула друкарський процес як взаємодію інформаційного, енергетичного і матеріального потоків для від- творення інформації на друкованому відбитку; встановила аналітичні вирази енергетичного, інформаційного і матеріального потоків, що описують взаємодію всіх складників друкарського контакту; з позицій термодинаміки необоротних процесів теоретично обґрунтувала стан і поточні властивості друкарського контакту як часову структуру, що реалізується в кожній точці постійних елементів друкарського контакту і компенсується змінними елементами для забезпечення перенесення інформаційного потоку; експериментально встановила вплив інтенсивних енергетичних потоків на задруковуваний матеріал і обґрунтувала технологічні режими інтенсифікації закріплення фарби і стабілізації відбитків. Теоретичні основи, викладені в дисертації, знайшли застосування в галузі, що було підтверджено актами впровадження і відгуками з підприємств, у нових технологічних процесах і конструкціях друкарських машин, у навчальному процесі підготовки фахівців за освітньо-професійними програмами бакалаврів, спеціалістів, магістрів.

З 2008 року Олена Михайлівна очолює кафедру репрографії ВПІ НТУУ «КПІ». Тут виявилися її організаторські здібності. За короткий час здійснено структуризацію кафедри, оптимізовано навчальні і робочі навчальні плани згідно актуальних вимог сучасних тенденцій розвитку вищої освіти і технічного прогресу видавничо-поліграфічної галузі. Штат кафедри поповнився док- 
торами і кандидатами наук. Здійснено заходи щодо акредитації підготовки фахівців освітньокваліфікаційних рівнів «спеціаліст» двох спеціальностей «Технології електронних мультимедійних видань» та «Матеріали видавничо-поліграфічних виробництв», - а також ліцензування цих спеціальностей за освітньокваліфікаційним рівнем «магістр». Триває підготовка фахівців денної і заочної форм навчання всіх освітньо-кваліфікаційних рівнів - бакалавр, спеціаліст, магістр спеціальності «Комп'ютерні технології та системи видавничополіграфічних виробництв». Розширилися напрямки наукових досліджень відповідно до потреб галузі та інформаційного суспільства в цілому.

Побажаємо Олені Михайлівні у ці святкові ювілейні дні міцного здоров'я, талановитих учнів, нових цікавих оригінальних ідей, творчих успіхів, наснаги, завзяття на благо нашої Батьківщини!

Петро Киричок, директор ВПІ НТУУ «КПІ» 